Łukasz DONAJ

Uniwersytet im. Adama Mickiewicza w Poznaniu

\title{
Współczesny kryzys społeczno-polityczny na Ukrainie jako przykład cykliczności (chroniczności?) procesów politycznych
}

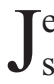
ednym z zadań, jakie stawia się przewidywaniu, jako nauce, jest spełnienie jej funkcji praktycznej, która polega m.in. na określeniu stopnia wiarygodności przewidywania. Stopień ów przewidywanie dziedziczy po prawach wyprowadzonych dedukcyjnie z praw statystycznych, odnoszących się do konkretnych faktów. Składnikami wiarygodności w tym dziedziczeniu jest zarówno stopień pewności prawdziwości, jak też treść praw przyczynowych, koegzystencjalnych i statystycznych ${ }^{1}$. Postępowanie prognostyczne musi wychodzić z rozpoznania sytuacji dotychczasowej ${ }^{2}$. Politolog zajmuje się teraźniejszością, ale ściśle pod

1 J. Kukułka, Teoria stosunków międzynarodowych, Warszawa 2000, s. 252-253. Naukę pojmować należy jako zespół czynności prowadzących do zgromadzenia zasobu należycie uzasadnionej wiedzy o rzeczywistości (nauka w sensie pragmatycznym) czy też jako zespół uzyskanych w ten sposób twierdzeń (nauka w sensie apragmatycznym). Zob. szerzej także: A. Redelbach, Wstęp do prawoznawstwa, Poznań 1996, s. 12-14; L. Wolpert, Nienaturalna natura nauki, Gdańsk 1996; K. J. Stryjski, Prognozowanie i symulacje międzynarodowe, Łódź 2004; B. Guzik, D. Appenzeller, W. Jurek, Prognozowanie i symulacje. Wybrane zagadnienia, Poznań 2004.

2 Diagnoza tej sytuacji powinna być na tyle rozwinięta, aby ustalała istniejąca fazę jej zmienności oraz przewidywane następstwo faz przyszłych. Do naukowego przewidywania o funkcji praktycznej potrzebna jest diagnoza rozwojowa, zwana też diagnozą prognostyczną. Polega ona na dociekaniu przyszłego rozwoju branego pod uwage procesu lub zjawiska na podstawie dotychczasowych etapów diagnoz cząstkowych (typologicznej, genetycznej, znaczenia i fazy) oraz ich ustaleń. Diagnoza prognostyczna stanowi zarazem ich wynik i uzupełnienie przez wnioskowanie głównie z ukrytych tendencji rozwojowych, a czasem także na podstawie znanych praw przyczynowych (np. ekstrapolacji). W obu przypadkach jest to rozumowanie probabilistyczne, które prowadzi do niepewnych hipotez. Albowiem nawet ukryte tendencje rozwojowe są uwarunkowane specyficzną sytuacją badanych zjawisk i procesów, a zwłaszcza występowaniem odpowiednich uregulowań i zakłóceń, które w stosunkach międzynarodowych - podobnie jak we wszystkich rodzajach stosunków społecznych - odgrywają dużą rolę. J. Kukułka, op. cit., s. 253. 
kątem prognozowania przyszłości, co nierzadko wkracza w krąg futurologii - zwłaszcza, gdy jego warsztat naukowy nie jest w pełni doskonały, a on sam przejawia skłonność do zbyt pewnego siebie formułowania ocen. Historyk referuje i ocenia wydarzenia minione, po czym potrzebuje dystansu czasowego. Związek jednak między tymi dyscyplinami z pewnością istnieje, i upraszczając rzec można, że historia może być nauką pomocniczą politologii ${ }^{3}$.

Co prawda dwadzieścia kilka lat niepodległej Ukrainy to stanowczo za mało, by móc w pełni rzetelnie stawiać hipotezy odnośnie rozwoju sytuacji wewnętrznej i zewnętrznej tego państwa, niemniej jednak, już to pozwala nam snuć pewne przypuszczenia. $\mathrm{Z}$ racji ograniczonej objętości artykułu przeanalizowane zostaną w nim tylko wybrane wydarzenia z najnowszej historii państwa nad Dnieprem.

\section{Ukraina 1999/2000}

Wybory prezydenckie 1999 roku wykazały, że jedyną przeciwwage dla groźby powrotu komunizmu stanowiła dotychczasowa władza. W drugiej turze wyborów (14 listopada 1999 roku) zwyciężył Leonid Kuczma, uzyskując dużą przewagę nad kandydatem komunistów, Petrem Symonenką ${ }^{4}$. Jednakże wyborcze zwycięstwo dawnego prezydenta zostało osiagnięte przy zastosowaniu brutalnych nacisków ze strony państwa i licznych nadużyć. Inna niepokojąca tendencja w życiu politycznym wiąże się z serią zabójstw i zamachów na liderów politycznych, włącznie z tragiczną śmiercią w niewyjaśnionych okolicznościach Wiaczesława Czornowiła w dniu 26 marca 1999 roku ${ }^{5}$.

Prezydent faktycznie kontrolował wymiar sprawiedliwości, system bankowy, władze w regionach, największą część karteli gospodarczych

3 M. Kosman, O pożytku historii dla politologa, „Przegląd Politologiczny” 1998, nr 1-2. Zob. także: Przeszłość odległa i bliska: Marcelemu Kosmanowi w sześćdziesiata rocznice urodzin, pod red. K. Robakowskiego, Poznań 2000.

${ }^{4}$ Zob. szerzej: J. Kluczkowski, Kto przekona niezdecydowanych, „Polska Zbrojna” nr 45, 6 listopada 1999 r.; W. Tołokin, Ukraina, wybory bez wyboru, „Argumienty i Fakty" 1999, nr 44.

5 I ce wy nazywajete stabilnistju, „Deń” nr 183, 5 października 1999 r. Na temat W. Czornowiła zob.: Chto je chto w Ukrajini, pod red. J. Marczienko, O. Tieliemko, Kijów 2001, s. 496. 
i wszystkie ważne media ${ }^{6}$. A. Łukaszenko, do którego L. Kuczma był coraz częściej porównywany, osiagnął to szybciej i bezpośrednio - wywłaszczając prywatne banki, łamiąc konstytucję i otwarcie naciskając na wymiar sprawiedliwości. Administracja prezydenta Ukrainy nie stosowała tak prymitywnych metod $^{7}$. Kompetencje parlamentu wobec organów władzy wykonawczej były bardzo ograniczone - można nawet mówić o marginalizacji parlamentu $\mathrm{w}$ państwowym procesie decyzyjnym. W praktyce przewaga prezydenta była jeszcze większa niż wynika to $z$ Konstytucji, a zdarzało się, że urzędnicy administracji prezydenta okresowo wykonywali w rzeczywistości obowiązki poszczególnych ministrów. System ten był o tyle niestabilny, że zakres realnych kompetencji konkretnych organów (z wyjątkiem prezydenta) zależał od osób, zajmujących odpowiednie stanowiska ${ }^{8}$. Kluczowe decyzje podejmował prezydent, pośrednio bądź bezpośrednio autoryzując decyzje premiera. Stąd też wielki wpływ na kształt tych rozwiązań miała administracja prezydenta i Sekretariat RBNiOU. Rząd miał tu znaczenie drugorzędne. Wojewodowie, choć silnie uzależnieni od prezydenta, dysponowali stosunkowo dużą samodzielnością decyzyjną i często współpracowali na rzecz realizacji lokalnych interesów z szefami rad obwodowych i merami wielkich miast ${ }^{9}$.

\section{Tzw. Pomarańczowa Rewolucja i jej następstwa}

Wydarzenia nazwane Pomarańczowa Rewolucja poprzedzały m.in. wybory parlamentarne w 2002 roku, podczas których organizacje społeczne odnotowały bardzo wiele naruszeń prawa ${ }^{10}$. Niemniej jednak za kotarą kabiny okazało się, że mimo natrętnej kampanii w mediach przeciwko opozycji, i mimo działania czynnika administracyjnego, spora

6 Zob. szerzej: W. Pawliw, Kuczma pod prasa, „Wprost” z 8 kwietnia 2001 r.

7 K. Bachmann, O. Iwaniak, Prezydencka republika. Czy Leonid Kuczma kroczy śladami Aleksandra Łukaszenki?, „Rzeczpospolita” z 24 listopada 1999 r.

8 Zob. szerzej: T. A. Olszański, Raport 2001. Część II - Ukraina, za: www.uxa.osw.waw.pl (data wejścia na strony: 19 grudnia 2001 r.); Rocznik strategiczny 2001/2002. Przeglad sytuacji politycznej, gospodarczej $i$ wojskowej $w$ środowisku międzynarodowym Polski, pod red. R. Kuźniara, Warszawa 2002, s. 229.

${ }^{9}$ Ibidem.

10 Zob. P. Kościński, Demokracja na 90 procent. Ukraina. Wygrana bloku Wiktora Juszczenki. Kolejki do urn. 10 tysięcy przypadków naruszeń prawa wyborczego?, „Rzeczpospolita” z 2 kwietnia 2002 r. 
część głosujących nie bała się oddać swego głosu zgodnie z sumieniem $^{11}$.

Mimo porażki bloku prezydenckiego, ukraińska opozycja pozostała zbyt zróżnicowana ideologicznie oraz podzielona w kwestii przywództwa, aby uzyskać realne wpływy. Prezydent L. Kuczma utrzymał przy tym efektywne możliwości rozgrywania animozji wśród dążącej do jego odwołania radykalnej opozycji ${ }^{12}$. Zgodnie z normami konstytucyjnymi szefem rządu został polityk desygnowany przez prezydenta - Wiktor Janukowicz. Zatwierdzenie nowego premiera powiodło się nie tylko ze względu na głosy frakcji proprezydenckich, także dzięki frakcji „Nasza Ukraina". Nowy rząd dysponował ograniczonym mandatem merytorycznym, ale też i przychylnością głównych oligarchów ${ }^{13}$.

Dodać należy, że kryzys polityczny na Ukrainie miał skomplikowane podłoże. Głównym jego elementem był skandal związany z oskarżeniami prezydenta L. Kuczmy o zlecenie zamordowania G. Gongadze, który wybuchł pod koniec 2000 roku $^{14}$. Nieprzejednane stanowisko ugrupowań opozycyjnych, skupionych wokół „Forum Ocalenia Narodowego”, uniemożliwiło podjęcie dalszych rozmów, a słabość opozycji (zwłaszcza brak pozytywnego programu, wykraczającego poza hasło „Ukraina bez Kuczmy" oraz brak jednolitego przywództwa) zapewniły prezydentowi zwycięstwo w tej konfrontacji ${ }^{15}$.

11 Zob.: Kantrol. Tysiacza par głaz prosliedit za wyborami, ,Stoliczka” z 25 marca 2002 r.; M. Wojciechowski, Kto zbuduje rzqd? Niepetne wyniki wyborów parlamentarnych na Ukrainie, „Gazeta Wyborcza” z 2 kwietnia 2002 r., J. Demin, Sudbu Ukrainy rieszat gałosa ,miortwych dusz”, ,Wiecziernije Wiesti” z 23 marca 2002 r.

12 Zob.: Rocznik strategiczny 2002/2003. Przeglad sytuacji politycznej, gospodarczej $i$ wojskowej $w$ środowisku międzynarodowym Polski, pod red. R. Kuźniara, Warszawa 2003, s. 227. Zob. także: J. Omielczienko, Diewjat w odnoj uprjażkie: parljamientskoje bolszinstwo sformirowano biez „Nasziej Ukrainy”, „Siewodnia” z 20 września 2002 r.

13 Rocznik strategiczny 2002/2003..., op. cit., s. 229. Zob. także: A. Smirnow, A. Szewczienko, Wiktor Janukowicz. Gława Donieckoj obłastnoj gosudarstwiennoj administracji, „Korriespondient” z 19 listopada 2002 r.; B. Bobrow, Pierwyj donieckij premier, „Diełowaja stolica” z 25 listopada 2002 r.

14 Zob. szerzej: Kalendarium kryzysu, MAW, „Gazeta Wyborcza” z 27 kwietnia 2001 r.; oraz: P. Kościński, Z kim i przeciw komu. Czy opozycja na Ukrainie to komuniści i faszyści, jak uważa prezydent Leonid Kuczma, „Rzeczpospolita” z 30 marca 2001 r.; Rozmowa z J. Mostowoj, Bój nie tylko o Kuczmę, przeprowadzona przez J. Strzałkę, „Tygodnik Powszechny” z 13 marca 2001 r.

15 T. A. Olszański, Raport 2001. Część II - Ukraina, za: www.uxa.osw.waw.pl (data wejścia na strony: 19 grudnia 2001 r.). 
Izolacja międzynarodowa Ukrainy nasiliła się ponadto w związku ze sprawą domniemanej sprzedaży systemów ochrony przeciwlotniczej „Kolczuga” reżimowi irackiemu ${ }^{16}$. Wraz z wybuchem afery (w drugiej połowie 2002 roku) ukraińska dyplomacja (a przede wszystkim osoba prezydenta) utraciła kredyt zaufania na Zachodzie, głównie w USA i NATO. W warunkach narastającego chaosu politycznego, przy wzrastającej w siłę szeroko rozumianej opozycji, a także dzięki ożywieniu i umocnieniu struktur powstającego społeczeństwa obywatelskiego sytuacja na Ukrainie dojrzała do kolejnych kroków, jakimi była niezgoda na zafałszowanie wyników wyborów prezydenckich w 2004 roku ${ }^{17}$.

16 Zob. szerzej: A. Kiński, Tajemnice Kolczugi, za: www.polska-zbrojna.pl (data wejścia na strony: 6 grudnia 2003 r.); Tajemnica „,Kolczugi”, za: www.sieradz.mediacom.pl (data wejścia na strony: 6 grudnia 2003 r.).

17 Dwa lata przed planowanymi wyborami, w sierpniu 2002 roku prezydent L. Kuczma w wystąpieniu z okazji 11 rocznicy niepodległości Ukrainy stwierdził, że dla dalszego rozwoju kraju niezbędne jest przejście do systemu rządów parlamentarno-prezydenckich. Prezydent niejako tym samym zgodził się z większością postulatów proponowanych przez opozycję na kilka tygodni przed jej kolejnymi wystąpieniami w ramach akcji „Powstań Ukraino!” - praktycznie jednak w ten sposób spróbował przejąc inicjatywę. Reforma systemu politycznego Ukrainy - jak wnet zapowiedziały osoby zbliżone do kręgów prezydenckich - nie przewidywała przeprowadzenia wcześniejszych wyborów zarówno prezydenckich, jak i parlamentarnych. Przewidywano, że Rada Najwyższa Ukrainy nie będzie sama w stanie przeprowadzić takiej reformy. Dorzuciwszy do tego pełnomocnictwa prezydenta, który może w mało widoczny dla społeczeństwa sposób destabilizować prace parlamentu, mogło się okazać, że wina za cały kryzys polityczny w kraju spocznie na parlamencie. A wtedy - choć trzecia kadencja L. Kuczmy była mało prawdopodobna (lecz bynajmniej nie niemożliwa - wspominano m.in. o tym, że akty prawne zabraniające trzykrotnej prezydentury nie muszą dotyczyć L. Kuczmy, np. Konstytucja przyjęta była już w czasie jego drugiej kadencji) - łatwiej byłoby wprowadzić na fotel prezydenta kogoś, kto - tak jak W. Putin B. Jelcynowi - zdołałby zabezpieczyć interesy L. Kuczmy i jego bliskich. Jak pokazały kolejne miesiące reformę konstytucyjną kraju zdołano jednak przeprowadzić. Opracowano na podstawie: I. Kocina, Leonid Kuczma: dlja dalniejsziewo razwitija stranie nieobchodim pieriechod $k$ parlamientsko-priezidientskoj riespublikie, „Fakty” z 28 sierpnia 2002 r.; K. Bondarienko, Strasti po oppoziciji. Politiczieskaja kolokolnja, „Korriespondient” z 30 sierpnia 2002 r.; Obliczja Ukrajini 2002. Szczoricznij ukrajiskij żurnat, pod red. N. Właszczienko, Kijów 2003, s. 107-110; J. Zuszczik, A. Smirnow, P. Stiebnickij, Nastuplienije oppoziciju. Chronika protiesta, „Korriespondient” z 27 września 2002 r.; I. Kocina, Postojannij priedstawitiel priezidienta $w$ parlamientie Alieksandr Zadorożnij: rieforma sistiemy Ukrainy nie podrazumiewajet prowiedienija dosrocznich wyborow, „Fakty” z 29 sierpnia 2002 r.; Poczatek kuczmizacji konstytucji?, za: www.wprost.pl (data wejścia na strony: 30 grudnia 2003 r.); Konstitucjonnyj Sud potwierdił prawo L. Kuczmy baloti- 
Przed samymi wyborami prezydenckimi 2004 roku rozpatrywano przede wszystkim możliwość spełnienia się czterech scenariuszy wydarzeń: 1) demokratyczne zwycięstwo W. Juszczenki: takowe miało być przedstawione na Zachodzie jako zwycięstwo demokracji i prozachodniego kursu Ukrainy. Wskazywano jednak także na to, że ,jeden prezydent demokracji nie czyni”. Po pierwsze - nie wiadomo było jaki wpływ na podejmowanie decyzji przez W. Juszczenkę miałoby mieć jego otoczenie polityczne (a warto pamiętać, że nie jest to struktura jednorodna, a raczej „pospolite ruszenie”, w wielu miejscach znacznie się różniące między soba); po drugie - nadal nie było wiadomo jaki będzie los reformy politycznej kraju; 2) demokratyczne zwycięstwo W. Janukowicza: jeśli tak by się miało stać, mogłoby się okazać, że - w porównaniu z W. Juszczenko - będzie miał większe pole manewru. Będzie mógł się nawet ostatecznie określić, co z kierunkiem euro-atlantyckim (hasła o całkowitym odejściu od niego traktować należało w dużej mierze jako grę wyborczą). Taki kurs niósłby jednak za sobą konieczność dostosowania standardów ukraińskiej polityki do standardów europejskich, gdy tymczasem można było odnieść wrażenie, że W. Janukowicz wolałby by różnice te pozostały nadal zauważalne (co niosłoby za sobą określone korzyści chociażby materialne - mniejsza przejrzystość sprzyjać nadal miała wielu niejasnym interesom); 3) niedemokratyczne zwycięstwo W. Janukowicza: tu możliwe byłyby 3 warianty: a) zwycięstwo wskutek oczywistych oszustw, co mogłoby pociagnąć daleko idące ochłodzenie stosunków z Zachodem; b) wykorzystanie demokratycznego zwycięstwa do ograniczenia demokracji w kraju; c) zwycięstwo wskutek oczywistych oszustw i dalej - też wykorzystanie tego do ograniczenia demokracji w kraju; 4) uznanie wyborów za nieważne lub wręcz ich odwołanie: scenariusz ten był również rozpatrywany, lecz wydawało się, że był on z wyżej wymienionych najmniej prawdopodobny. Wtedy władzę znów - a raczej nadal - posiadałby obóz L. Kuczmy. Jednak

rowatsja $w$ Priezidienty Ukrainy w 2004 godu, za: www.liga.ua (data wejścia na strony: 30 grudnia 2003 r.); D. Dżangirow, Konstitucjonnaja rieforma i słaboje zwieno oppoziciji, „Poniedielnik” z 7 kwietnia 2003 r.; Kuczma zapewnit sobie prezydenturę, za: www.wprost.pl (data wejścia na strony: 24 grudnia 2003 r.); Grazdanie Ukrainy wyskazywajyt niegodowanie diejstwiami $w$ parliamentie narodnych dieputatow ot opozycji, za: www.liga.ua (data wejścia na strony: 25 grudnia 2003 r.). 
mogłoby to grozić - w o wiele większym stopniu niż w przypadku scenariuszy nr 2 i 3 - wariantem gruzińskim ${ }^{18}$.

W wyniku tzw. Pomarańczowej Rewolucji prezydentem na Ukrainie został Wiktor Juszczenko ${ }^{19}$. W czasie kampanii wyborczej i samego głosowania na Ukrainie miało miejsce nienotowane od 1991 roku ożywienie polityczne społeczeństwa. Po pierwszych sygnałach o licznych błędach w spisach wyborczych (część z nich mogła mieć charakter manipulacji), setki tysięcy ludzi podejmowały działania w celu ich sprostowania. Nie byli to wyłącznie zwolennicy kandydatów opozycyjnych, choć ci ostatni zapewne stanowili większość. Ogromne było też zaangażowanie, przede wszystkim ludzi młodych, w kampanię W. Juszczenki. Ze względu na to, że każdy z 24 kandydatów miał prawo zgłaszać swych przedstawicieli do komisji wyborczych, liczyły one często 30-40 osób; łącznie w ich skład weszło około miliona osób. Do tego trzeba doliczyć mężów zaufania głównych kandydatów obecnych w większości komisji, tj. co najmniej sto tysięcy osób, bezpośrednio zaangażowanych w proces wyborczy. Była to dla nich „szkoła demokracji”, bez względu na to, jakiego kandydata reprezentowali. Ta mobilizacja społeczna stanowiła nową jakość w ukraińskim życiu publicznym. Trwała ona przez całość wyborów przez czas ewentualnych sporów o to, kto je wygrał. Było jednak wielce prawdopodobne, że może się następnie rozmyć (tak jak to miało miejsce w 2001 roku), o ile przywódcy polityczni (przede wszystkim z szeroko pojętego otoczenia W. Juszczenki) nie będą umieli jej przekształcić w ruch na rzecz budo-

18 Jak się okazało, zarówno obóz władzy, jak i szeroko rozumiana opozycja ukraińska były chyba zaskoczone faktem, że to co się dokonało w Gruzji udało się i na Ukrainie. Po wydarzeniach Rewolucji Róż, na Ukrainie mówiono o Rewolucji Kasztanowej. Ostatecznie przybrała ona kształt Rewolucji Pomarańczowej. Zob. szerzej: W. Sizintow, Sorwat wybory newazmożno. Pa krajniej miere, w ramkach diejstwujuszcziej Konstituciji i zakonow Ukrajini, „Diełowaja Niedielja” z 7-13 października 2004 r.; D. Szierr, Wybori w Ukrajinie: wzaimodiejstwie wnutriennich $i$ wniesznich faktorow, „Zierkało Niedieli” z 9 października 2004 r.

19 Szerzej na temat tzw. Pomarańczowej Rewolucji, jej przebiegu, konsekwencji, a także sytuacji politycznej na Ukrainie po wyborach parlamentarnych z marca 2006 roku zob. m.in.: „Pomarańczowa rewolucja” - szansa dla ukraińskiej transformacji politycznej, tom studiów pod red. A. Furiera, Szczecin 2006 r.; Ł. Donaj, Pomarańczowa Rewolucja na Ukrainie z trockizmem $w$ tle, „Środkowoeuropejskie Studia Polityczne" 2005, nr 2. 
wy instytucji społeczeństwa demokratycznego, samorządów studenckich i lokalnych itd. ${ }^{20}$

Co prawda w nowym rządzie - mimo, iż jego formowanie odbywało się przede wszystkim według zasady nagradzania za zasługi i spłaty zobowiązań - pojawili się ludzie zdolni do demontażu starego systemu i przygotowania gruntu dla zasadniczych reform zapowiadanych przez prezydenta $^{21}$, pojawiło się też i pytanie: czy będą umieli je przeprowadzić? Zdaniem Anny Górskiej z Ośrodka Studiów Wschodnich nadrzędnym celem stawianym sobie przez nową władzę było zwycięstwo w wyborach parlamentarnych w marcu 2006 roku, szczególnie ważnych w związku ze zmianą Konstytucji i zasadą powoływania rządu przez partię/koalicję, która zdobędzie większość. Dopiero zwycięstwo w tych wyborach pozwolić miało na utrwalenie nowej władzy. Dlatego należało się spodziewać, że rząd skupi się raczej na demontażu systemu władzy stworzonego przez L. Kuczmę i przygotowaniu gruntu dla reform, ale nie ich wdrożeniu. W szczególności dotyczyło to reform społecznych (reforma emerytalna, reforma służby zdrowia), które wiążą się bardziej z kosztami niż szybko odczuwalnymi społecznie efektami. Dodawszy do tego możliwość wystąpienia konfliktów związanych z utrzymaniem wewnętrznej spójności i zespołowego działania rządu, było wielce prawdopodobne, że przed Ukrainą stanęło zadanie trudniejsze, niż samo przeprowadzenie Pomarańczowej Rewolucji - zadanie budowy stabilnych podstaw państwa ${ }^{22}$. I jak się później okazało - zadanie to chyba przerosło polityków. Nie jest to jednak li tylko wina wewnętrznych problemów Ukrainy, ale także - a może ...przede wszystkim?... - państw, które zainteresowane są ciagłym kryzysem władzy w państwie nad Dnieprem (i - bynajmniej - mowa nie tylko o Federacji Rosyjskiej).

Początek prezydentury W. Juszczenki przyniósł dyplomatyczną ofensywę Ukrainy na Zachodzie (acz, co warte podkreślenia, miejscem jego pierwszej oficjalnej wizyty zagranicznej była stolica Rosji). Odwiedził m.in. Strasburg, gdzie wystapił na forum Zgromadzenia Parlamentarnego Rady Europy, Kraków i Oświęcim oraz forum ekonomiczne w szwajcar-

20 Zob. szerzej: T. A. Olszański, Ukraina przed drugq tura wyborów prezydenckich, za: www.osw.waw.pl (data wejścia na strony: 18 listopada 2004 r.).

${ }^{21}$ Zob.: A. Górska, Nowy rząd Ukrainy - perspektywy $i$ zagrożenia, za: www.osw.waw.pl (data wejścia na strony: 17 lutego 2005 r.).

22 Zob. ibidem. 
skim Davos. Podczas swych podróży po Europie W. Juszczenko odważnie i dość jasno sprecyzował priorytety zagraniczne nowej władzy, w praktyce - jak się wydawało - oznaczające odrzucenie dotychczasowej ,polityki wielowektorowej”, uprawianej z różnym skutkiem przez Ukrainę L. Kuczmy, oraz kurs na instytucjonalną integrację z Unią Europejską ${ }^{23}$.

Oczywiście zmienianie świata należy zacząc od siebie, a tymczasem perspektywę integracji euroatlantyckiej Ukrainy oddalają i kryzysy polityczne, które co rusz przetaczają się przez to państwo. W kwietniu 2007 roku rozgorzał kolejny, kiedy prezydent W. Juszczenko rozwiązał parlament. Przyczyną tej decyzji było dążenie koalicji premiera Wiktora Janukowycza do utworzenia 300-osobowej większości, pozwalającej na zmianę Konstytucji, łącznie z likwidacją urzędu prezydenckiego. W. Juszczenko oskarżył koalicjantów, że przekupują w tym celu deputowanych opozycji, proponując im za zmianę barw politycznych pieniądze i stanowiska. Koalicja, nie chcąc podporządkować się decyzji prezydenta, zorganizowała w Kijowie wielotysięczne protesty, w końcu jednak zgodziła się na przedterminowe wybory - które miały miejsce 30 września 2007 roku $^{24}$.

Tyle tylko, że przeprowadzenie wyborów nie usunęło zasadniczych przyczyn kryzysu politycznego, u źródeł którego leży słabość ukraińskiego systemu politycznego i prawnego ${ }^{25}$. W owych przedterminowych

23 Rocznik Strategiczny 2004/2005. Przeglą sytuacji politycznej, gospodarczej $i$ wojskowej w środowisku międzynarodowym Polski, pod red. R. Kuźniara, Warszawa 2005, s. 228.

24 Zob.: Kwaśniewski: Kryzysy polityczne oddalaja perspektywę integracji europejskiej Ukrainy, cheko, PAP, za: www.gazeta.pl (data wejścia na strony: 2 stycznia 2008 r.). Szerzej na temat przyczyn i przebiegu tego kryzysu zob. m.in.: W. Radziwinowicz, Proprezydencka Nasza Ukraina chce obalić rzad Wiktora Janukowycza, za: www.gazeta.pl (data wejścia na strony: 2 stycznia 2008 r.); W. Radziwinowicz, Juszczenko traci władzę, za: www.gazeta.pl (data wejścia na strony: 2 stycznia 2008 r.); Kryzys polityczny na Ukrainie, ,Tydzień na Wschodzie” nr 5 z 4 kwietnia 2007 r.; T. A. Olszański, Perspektywy ewolucji kryzysu politycznego na Ukrainie, „Tydzień na Wschodzie" nr 6 z 12 kwietnia 2007 r.; A. Górska, Porozumienie o wyborach - pierwszy krok do rozwiazania kryzysu na Ukrainie, „Tydzień na Wschodzie” nr 9 z 9 maja 2007 r.

25 Niejednoznaczność zapisów Konstytucji oraz ustaw określających podział kompetencji między poszczególnymi organami władzy umożliwiła stronom konfliktu dowolną ich interpretację i instrumentalne traktowanie. W ciągu ostatnich kilku lat doszło do ograniczenia efektywności działań, a w niektórych przypadkach nawet paraliżu instytucji państwa. Kryzys stworzył niebezpieczne precedensy. Rezygnacja 
wyborach - 30 września 2007 roku - wygrała „Partia Regionów”, jednak największy sukces odniósł „Blok Julii Tymoszenko”, poparcie dla którego wzrosło od wyborów 2006 roku o około 9 punktów procentowych. „,Blok Julii Tymoszenko” wraz z „Nasza Ukraina” zdobył większe poparcie niż „Partia Regionów”.

I znów na Ukrainie doszło do politycznych ,przepychanek” przy tworzeniu koalicji i powoływaniu premiera. Ostatecznie, dopiero 18 grudnia 2007 roku doszło do ukonstytuowania się rządu J. Tymoszenko ${ }^{27}$.

z odwołania się do orzeczenia Sądu Konstytucyjnego i dyskredytacja tej instytucji stwarza schemat działania politycznego, w którym nie ma miejsca na oceniającą i powstrzymującą funkcję wymiaru sprawiedliwości. Z kolei rezygnacja z mandatów poselskich jako sposób doprowadzenia do wyborów tworzy zagrożenie, że każda siła polityczna, która uzyska w przyszłych składach Rady Najwyższej 151 mandatów, może, nawet bez zasadnych przyczyn, uniemożliwić pracę parlamentu i wymusić kolejne przedterminowe wybory. Do trwałego rozwiązania konfliktu i odbudowania stabilności w państwie konieczny jest kompromis między ośrodkiem prezydenckim a ośrodkiem rządowym, którego konsekwencją będzie wypracowanie kompleksowych i jednoznacznych rozwiązań ustrojowych, gwarantujących zakres i poszanowanie wzajemnych prerogatyw. Nieodzownym elementem tych działań jest kolejna reforma Konstytucji oraz reforma wymiaru sprawiedliwości, która pozwoli na pojawienie się niezależnej i efektywnej władzy sądowniczej. Szanse takiego rozwiązania istnieją, choć trudno ocenić ich prawdopodobieństwo. Wymagałoby ono zmiany w myśleniu i praktyce działania politycznego ukraińskich elit. Możliwość trwałego rozwiązania konfliktu i zbudowania stabilności instytucjonalnej pojawi się w momencie, gdy główni gracze uznają, że jasne, oparte na jednoznacznych zapisach prawnych reguły gry lepiej zabezpieczą ich interesy niż obecny nieprecyzyjny i konfliktogenny system prawny. A. Górska, Szansa na wyjście z kryzysu politycznego na Ukrainie, „Tydzień na Wschodzie” nr 12 z 30 maja 2007 r. Zob. także: Rocznik Strategiczny 2007/2008. Przeglad sytuacji politycznej, gospodarczej i wojskowej w środowisku międzynarodowym Polski, pod red. R. Kuźniara, Warszawa 2008, s. 200-204.

26 T. A. Olszański, Wybory parlamentarne na Ukrainie, „Tydzień na Wschodzie" nr 23 z 3 października 2007 r.

27 I znów - nie oznaczało to jednak, że zakończył się kryzys. Bo jak przewidywano, mogło się znów okazać, że choć osiągnięty poziom integracji przyniósł państwu nad Dnieprem już wiele korzyści - politycznych (jak wzmocnienie suwerenności i ustabilizowanie swej pozycji w europie), ale także gospodarczych i społecznych (jak istotne obniżenie barier w handlu z UE, wsparcie na drodze członkostwa do WTO czy chociażby finansowa pomoc techniczna z UE - to z uwagi na niestabilna sytuację polityczną i waśnie polityków na samej Ukrainie, perspektywa dalszej, pogłębionej integracji ze strukturami euroatlantyckimi (notabene, kwestia ewentualnego członkostwa w NATO jest jeszcze bardziej „mglista”) znów pozostanie w sferze deklaracji i szczytnych zamierzeń. Inną sprawą jest także problem, czy dla Ukrainy - promowana swego czasu - polityka wielowektorowości nie jest najlep- 


\section{Ukraina 2009/2010}

Później rytm dyskursu politycznego na Ukrainie był podporządkowany wyborom prezydenckim w 2010 roku, dlatego też cała machina propagandowa trzech bloków skupiła się na oczernianiu przeciwników. To także prawdopodobnie doprowadziło do utraty stabilnej większości w parlamencie przez rząd J. Tymoszenko. Niektórzy obserwatorzy twierdzą, że odmowa poparcia gabinetu to implikacja bezpośrednich działań szefa kancelarii prezydenta W. Bałoby ${ }^{28}$. J. Tymoszenko zmuszona była wiele miesięcy radzić sobie bez stabilnej większości w Radzie Najwyższej. Co więcej, na jaw wyszły jej „konszachty” z W. Janukowyczem w sprawie przeforsowania zmian w Konstytucji, które zasadzały się na introdukcji pośrednich wyborów prezydenckich, dokonywanych przez deputowanych Rady Najwyższej, za czym miało iść przedłużenie kadencji obecnego parlamentu aż do 2014 roku, co miało implikować dalsze

szym rozwiązaniem na kolejne dekady. Zob. szerzej m.in.: T. A. Olszański, Chwilowe zażegnanie kryzysu politycznego na Ukrainie, „Tydzień na Wschodzie” nr 1(35) z 9 stycznia 2008 r. Zob. także: „,FT”: nowy ukraiński premier musi godzić wschód $z$ zachodem, mar, PAP, za: www.gazeta.pl (data wejścia na strony: 3 października 2007 r.); Juszczenko o formowaniu koalicji i opozycji, mar, jas, PAP, za: www.gazeta.pl (data wejścia na strony: 3 października 2007 r.); W. Radziwinowicz, Ukraińska koalicjada, za: www.gazeta.pl (data wejścia na strony: 4 października 2007 r.); W. Radziwinowicz, Ukraina ma wreszcie premiera, za: www.gazeta.pl (data wejścia na strony: 19 grudnia 2007 r.); Na Ukrainie koalicja większościowa, ale bez większości, MZ, „Gazeta Wyborcza” z 11 grudnia 2008 r.; M. Zawadzki, Polityczna wojna na Ukrainie w cieniu tragedii, „Gazeta Wyborcza” z 27-28 grudnia 2008 roku; Postowie nie dopuścili do wygłoszenia orędzia przez prezydenta w parlamencie na Ukrainie, barmi, PAP, za: www.gazeta.pl (data wejścia na strony: 13 czerwca 2009 r.); A. Dumała, Stosunki Ukrainy z Unia Europejska, w: Ukraina w stosunkach międzynarodowych, pod red. M. Pietrasia, T. Kapuśniaka, Lublin 2007; R. Foks, Perspektywy integracji Ukrainy ze strukturami euroatlantyckimi, w: Polska - Ukraina. Więcej niż sasiedztwo, pod red. M. S. Wolańskiego, Ł. Leszczenko, Wrocław 2006; Tymoszenko: Do NATO tylko przez referendum, mar, PAP, za: www.gazeta.pl (data wejścia na strony: 19 stycznia 2008 r.); Rosja do Ukrainy: Wejście do NATO to koniec dobrych stosunków, tan, PAP, za: www.gazeta.pl (data wejścia na strony: 22 stycznia 2008 r.); Ukraina oburzona na Rosję, alx, PAP, za: www.gazeta.pl (data wejścia na strony: 22 stycznia 2008 r.); Rosja - Ukraina: Spór o NATO, ricz, pap, za: www.gazeta.pl (data wejścia na strony: 23 stycznia 2008 r.); Ł. Donaj, GUUAM jako przykład wielowektorowości w ukraińskiej polityce, w: Europa Środkowo-Wschodnia w procesie globalizacji i integracji, pod red. T. Wallasa, Słubice 2003.

28 D. Strachota, Kim jest Julia Tymoszenko?, za: www.psz.pl (data wejścia na strony: 19 marca 2012 r.). 
rządy J. Tymoszenko na fotelu premiera, zaś W. Janukowyczowi miało to umożliwić zostanie głową państwa. Pomysł zamachu na jedną z podstawowych zasad demokracji - alternację rządów - nie powiódł się, ponieważ sprawa ta wyciekła do mediów w czerwcu 2009 roku i „Partia Regionów" stanowczo odcięła się od poparcia tego rozwiązania. Ponadto nowela wprowadzała de facto cenzurę prewencyjną w mediach i zaprzeczała jednemu z podstawowych aksjomatów tzw. Pomarańczowej Rewolucji - wolności słowa. Z kolei miesiąc wcześniej Sąd Konstytucyjny Ukrainy uznał, że rozpisanie przez Radę Najwyższą wyborów prezydenckich w dniu 25 października 2009 roku jest niezgodne z prawem i nakazał ich przeprowadzenie w styczniu 2010 roku. Była to kolejna porażka J. Tymoszenko ${ }^{29}$.

J. Tymoszenko przegrała wybory prezydenckie w 2010 roku $^{30}$. Komentując wyniki „Le Figaro” uznał je za rewanż W. Janukowycza, odsuniętego od władzy w 2004 roku. ,Juszczenko, ikona pomarańczowego obozu poniósł nieodwracalną klęskę. To kara za jego słabość, kompromisy i błędy" - pisał francuski dziennik, dodając, że ukraiński prezydent „nie dotrzymał złożonych obietnic”. Została już tylko J. Tymoszenko - ,jedyna depozytariuszka nadziei na zmianę" - pisała gazeta ${ }^{31}$.

29 Ibidem. Zob. także: Ł. Donaj, Julia Wołodymyriwna Tymoszenko - ,jedyna depozytariusza nadziei na zmiane” czy ,profesjonalna populistka”?, w: Kobiety we współczesnym świecie, pod red. M. Musiał-Karg, B. Seclera, Poznań 2010.

30 T. A. Olszański, Po wyborach prezydenckich Ukraina staje w obliczu zmiany rzadu, za: www.osw.waw.pl (data wejścia na strony: 7 kwietnia 2010 r.). Zob. szerzej: Z. Parafionowicz, współ. mwp., Polityk, którego wymyślit sowiecki kosmonauta. Wiktor Janukowycz przegrat Pomarańczowa Rewolucję. Wraca jako faworyt walki o prezydenture na Ukrainie, „Dziennik. Gazeta Prawna” z 15-17 stycznia 2010 r.; Чергові вибори Президента Украӥни 17.01.2010, za: www.cvk.gov.ua (data wejścia na strony: 26 stycznia 2010 r.); Rekordowa frekwencja $w$ ukraińskich wyborach. Zagłosowało już 45 proc. wyborców, tan, PAP, za: www.gazeta.pl (data wejścia na strony: 17 stycznia 2010 r.); Janukowycz i Tymoszenko $w$ drugiej turze wyborów na Ukrainie, bart, za: www.gazeta.pl (data wejścia na strony: 17 stycznia 2010 r.); P. Pogorzeliski, Ten trzeci, „Nowa Europa Wschodnia” 2009, nr 6; Obie strony rozpoczynaja teraz mobilizacje nomenklatury, rozmowa z Kostem Bondarenko, politologiem, dyrektorem Kijowskiego Instytutu Problemów Zarządzania, przeprowadzona przez M. Potockiego, „Dziennik. Gazeta Prawna” z 19 stycznia 2010 r.; S. Biełkowski, Scenariusze dla Kijowa, „Ukrajinska Prawda” z 11 stycznia 2010 r., za: „Forum”, nr 3, z 18 stycznia 2010 r.; D. Kałan, Wybory w czasach zarazy, za: www.psz.pl (data wejścia na strony: 29 stycznia 2010 r.).

${ }^{31}$ Komentarze po wyborach: wygrała Rosja, Juszczenko to ,zdruzgotane nadzieje”, jagor, PAP, IAR, za: www.gazeta.pl (data wejścia na strony: 7 kwietnia 2010 r.). 
Po objęciu władzy przez W. Janukowycza „Partia Regionów” szybko i skutecznie sformowała większość parlamentarną i rząd, znacznie zwiększyła wpływ władzy wykonawczej na sądownictwo i przywróciła ustrój prezydencko-parlamentarny. Wszystkie te działania przebiegały przy zaskakująco nikłym przeciwdziałaniu opozycji. Jej słabość i dezorientację potwierdziła kampania przed jesiennymi wyborami lokalnymi, w wyniku których „Partia Regionów” istotnie zwiększyła wpływy. W otoczeniu prezydenta i kierownictwie „Partii Regionów” uznano to za sygnał do wzmożenia presji na „Blok Julii Tymoszenko”, tak aby przed wyborami parlamentarnymi doprowadzić do jej marginalizacji. Po zmianie Konstytucji powstała kolizja prawna: Rada Najwyższa została wybrana na 5 lat, jednak zgodnie z przywróconą normą Konstytucji jej kadencja trwa 4 lata. Według pierwszego wariantu wybory parlamentarne powinny odbyć się jesienią 2012 roku, według drugiego - wiosną 2011 roku. Partia Regionów zdecydowała się na kolejną nowelizację Konstytucji, zgodnie z którą wybory mają odbyć się w październiku 2012 roku. W ten sposób obóz rządzący zyskał czas na przeprowadzenie niepopularnych reform, a jednocześnie na odzyskanie poparcia w społeczeństwie dla „Partii Regionów”32.

Od zdymisjonowania rządu J. Tymoszenko wiosną 2010 roku Administracja Prezydenta, prokuratura i rząd dążyły do wykazania, że poprzednia ekipa rządowa dopuszczała się nadużyć i działała na szkodę kraju. J. Tymoszenko zarzucano m.in. nieprawidłowe wydatkowanie kwot, otrzymanych od Japonii za limity emisji $\mathrm{CO}_{2}$ oraz zakup nieodpowiednich samochodów dla służby zdrowia. Żadna z tych spraw nie została oficjalnie zakończona, jednak władze zdecydowały się na odsunięcie ich na bok, a postawienie zarzutu dotyczącego kontraktu gazowego, najbardziej ryzykownego z prawnego punktu widzenia, ale najbardziej nośnego politycznie. Z drugiej strony J. Tymoszenko miała jasno określony cel polityczny: utrzymanie i odbudowę popularności w społeczeństwie oraz zwartości partii tak, by móc myśleć o zwycięstwie w wyborach parlamentarnych. Jej zachowanie na sali sądowej oraz stałe zapowiedzi w wypowiedziach publicznych, że z pewnością zostanie aresztowana, a następnie uwięziona, świadczyły o tym, że nie tylko liczyła się ona z możliwością aresztowania, ale mogła je uważać za odpowiadające ce-

32 T. A. Olszański, Strategia władz Ukrainy wobec opozycji, za: www.osw.waw.pl (data wejścia na strony: 19 marca 2012 r.). 
lom jej strategii politycznej. Gdy w 2001 roku została aresztowana po odwołaniu ze stanowiska wicepremiera, wyszła z aresztu jako niekwestionowana przywódczyni ruchu sprzeciwu wobec rządów L. Kuczmy ${ }^{33}$.

W październiku 2011 roku sąd rejonowy skazał J. Tymoszenko na 7 lat pozbawienia wolności, oskarżoną o nadużycia przy zawieraniu kontraktów gazowych z Rosją w 2009 roku. Prócz wyroku więzienia J. Tymoszenko otrzymała trzyletni zakaz zajmowania stanowisk państwowych. Sąd zobowiązał ponadto byłą premier do wypłacenia państwowej firmie paliwowej Naftohaz Ukrainy odszkodowania w wysokości 1,5 mld hrywien ${ }^{34}$.

Na wyrok natychmiast zareagowało polskie Ministerstwo Spraw Zagranicznych: „Polska, podobnie jak cała Unia, z niepokojem obserwuje przebieg procesu byłej premier Ukrainy" - czytamy w oświadczeniu rzecznika $\mathrm{MSZ}^{35}$. Głosy oburzenia podniosły się w całej Zachodniej Europie $^{36}$. Przychylnego J. Tymoszence spojrzenia Zachodu nie zachwiały nawet dwuznaczne depesze amerykańskiego ośrodka analitycznego Stratford ujawnione przez WikiLeaks. Z analiz ośrodka wynikało, że w 2009 roku W. Putin stawiał na J. Tymoszenko - uważał, że choć nie jest tak prorosyjska jak W. Janukowycz, dla władzy porozumie się z Kremlem. Podpisała też korzystną dla Rosji umowę gazową. J. Tymoszenko i W. Janukowycz zabiegali o poparcie Moskwy pod koniec 2009 roku. „Podobno rosyjscy przywódcy powiedzieli wówczas Janukowyczowi, że przestaną stawiać na Tymoszenko, jeśli będzie uzgadniał z nimi kluczowe nominacje na stanowiska w przyszłym rządzie. Janukowycz miał się zgodzić” - czytamy w „Gazecie Wyborczej”. W. Putin jednak wciąż wolał porozumieć się z J. Tymoszenko, zmienił zdanie dopiero wtedy, gdy przekonał go prezydent W. Miedwiediew: „W końcu zgodził się zmienić front, ale pod warunkiem, że rosyjscy doradcy zostaną wysłani do centrali Służby Bezpieczeństwa Ukrainy (spadkobierczyni KGB), a nominacje w ukraińskim rządzie, zwłaszcza w resortach

33 M. Jaroszewicz, S. Matuszak, T. A. Olszański, Proces i aresztowanie Julii Tymoszenko, za: www.osw.waw.pl (data wejścia na strony: 19 marca 2012 r.).

34 Ukraina. Tymoszenko skazana na siedem lat więzienia, PAP, za: www.gazeta.pl (data wejścia na strony: 19 marca 2012 r.).

35 Tymoszenko skazana na siedem lat więzienia!, aw, wg, ga PAP IAR, za: www.gazeta.pl (data wejścia na strony: 19 marca 2012 r.).

36 K. Nieczypor, Ukraine: Tymoshenko's Conviction - Reactions And Comments, za: http://eastbook.eu (data wejścia na strony: 19 marca 2012 r.). 
siłowych i armii, będą nadawane w ścisłym porozumieniu z Moskwą. Listę takich ludzi miał zatwierdzać osobiście Putin"37.

Mimo, iż zakładano, że poprzez kasację wyroku czy amnestię J. Tymoszenko zostanie z więzienia wypuszczona - tak się nie stało. Sprawa J. Tymoszenki spowodowała m.in. odłożenie parafowania umowy stowarzyszeniowej UE z Ukrainą. S. Füle (unijny komisarz do spraw rozszerzenia i polityki sąsiedztwa) - który zaapelował do ukraińskich władz o umożliwienie J. Tymoszenko udziału w wyborach parlamentarnych, stwierdził, że od tego, czy październikowe (28 października 2012 roku) głosowanie odbędzie się zgodnie ze standardami demokratycznymi, zależy los dalszych stosunków Ukrainy i Unii Europejskiej ${ }^{38}$.

Nie sposób omawiając najnowszą historię Ukrainy nie wspomnieć o Euro 2012. Co ciekawe, wśród wszystkich najważniejszych sił politycznych od samego początku panował konsensus w kwestii organizacji mistrzostw. Turniej nie stał się dla władz okazją do działań propagandowych i wykorzystywania go w realizacji bieżących celów politycznych. Tylko w nielicznych wypowiedziach politycy „Partii Regionów” podkreślali, że przed objęciem władzy przez ekipę W. Janukowycza przygotowania do turnieju prowadzone były nieefektywnie i dopiero po wyborach prezydenckich w lutym 2010 roku nastapił przełom w przygotowaniach do imprezy. Z kolei główne partie opozycyjne nie wykorzystywały Euro do krytyki rządu - przynajmniej nie w trakcie zawodów. Wynikało to głównie $\mathrm{z}$ tego, iż rozmijałoby się to $\mathrm{z}$ dominującym w społeczeństwie

37 WikiLeaks: Putin popart Janukowycza za wpływ na ukraińskie stużby i obsade resortów, red, za: ww.gazeta.pl (data wejścia na strony: 19 marca 2012 r.).

38 Paweł Kowal prosi o spotkanie z Juliq Tymoszenko. "Jej sprawa wywotuje niepokój”, jb, PAP, za: www.gazeta.pl (data wejścia na strony: 19 marca 2012 r.). 25 czerwca 2012 roku w Charkowie rozpoczął się nowy proces przeciw J. Tymoszenko. Akt oskarżenia dotyczy nadużyć podatkowych firmy Zjednoczone Systemy Energetyczne Ukrainy (JESU), której prezesem J. Tymoszenko była w latach 1995-1997, a także ukrywania przez nią dochodów w latach 1997-1999. Śledztwo w tej sprawie toczyło się już w latach 2001-2004, ale zostało umorzone po objęciu przez J. Tymoszenko stanowiska premiera w 2005 roku. Przedawnienie tych zarzutów wobec niej zostało przerwane (w zgodzie z ukraińskim prawodawstwem) w związku ze skazaniem jej za inne przestępstwo i prokuratura zdecydowała o wznowieniu sprawy. Już pierwszego dnia nowego procesu sąd zdecydował o jego odroczeniu do czasu przeprowadzenia ekspertyzy medycznej, która ma stwierdzić, czy J. Tymoszenko, która obecnie przebywa w szpitalu, jest w stanie uczestniczyć w procesie. Zob. szerzej: T. A. Olszański, Ukraina: poczatek nowego procesu przeciwko Julii Tymoszenko, za: www.osw.waw.pl (data wejścia na strony: 4 sierpnia 2012 r.). 
pozytywnym stosunkiem do Euro 2012. Druga przyczyną była koncentracja opozycji niemal wyłącznie na walce o uwolnienie J. Tymoszenko i Jurija Łucenki. Przedstawiciele opozycji zwracali jednak uwagę na nadużycia finansowe członków władz podczas wydatkowania środków na organizację turnieju ${ }^{39}$.

Wybory już za kilka tygodni - przygotowują się do nich zarówno ugrupowania opozycyjne ${ }^{40}$, jak i tzw. „obóz władzy”. W tym ostatnim przeprowadzono m.in. przetasowania personalne, mające zwiększyć efektywność poszczególnych kluczowych instytucji państwowych, w tym głównie struktur siłowych oraz kontrolę nad nimi. 14 lutego 2012 roku W. Janukowycz odwołał Andrija Klujewa ze stanowiska pierwszego wicepremiera i ministra gospodarki, mianując go sekretarzem Rady Bezpieczeństwa Narodowego i Obrony, ale pozostawiając mu obowiązki szefa sztabu wyborczego „Partii Regionów”. 22 lutego 2012 roku nowym wicepremierem został Wałerij Choroszkowski, dotychczasowy minister finansów. Jest to kolejny etap trwającej od jesieni 2011 roku rekonstrukcji rządu Mykoły Azarowa, w trakcie której zmieniło się kierownictwo resortu spraw wewnętrznych, obrony, finansów i zdrowia, a także Służby Bezpieczeństwa Ukrainy, Rady Bezpieczeństwa Narodowego i Obrony oraz sztabu generalnego. Zmiany te zwiększają kontrolę prezydenta nad najważniejszymi instytucjami państwowymi, a ich głównym celem jest przygotowanie zwycięstwa w zbliżających się wyborach parlamentarnych i zapobieżenie poważniejszym protestom społecznym. Większość dokonanych zmian umacnia tzw. rodzinę, czyli środowisko polityczno-biznesowe skupione wokół syna prezydenta, Ołeksandra. Jednocześnie widać, że W. Janukowycz chce utrzymać w swym otoczeniu równowagę wpływów różnych grup w elicie władzy ${ }^{41}$.

W kontekście powyższego trzeba się zastanowić, czy kryzysy na Ukrainie są następstwem przede wszystkim zjawisk, jakie w demokra-

39 S. Matuszak, T. A. Olszański, Euro 2012 - niewykorzystana szansa Ukrainy?, za: www.osw.waw.pl (data wejścia na strony: 4 sierpnia 2012 r.). Zob. także: O. Pierowa, Bojkot, da nie tot. Ekspierty nie wieriat $w$ riealnost bojkotirowania Jewro-2012, „Argumenty i Fakty” 2012, nr 20.

40 Zob. szerzej np.: M. Żartowskaja, Na finisznoj kriwoj, „Fokus” z 18 maja $2012 \mathrm{r}$.

41 T. A. Olszański, współ. W. Konończuk, Personalne roszady we władzach Ukrainy elementem przygotowań wyborczych, za: www.osw.waw.pl (data wejścia na strony: 4 sierpnia 2012 r.). Zob. także: D. Orłow, Wsio budiet, „Fokus” z 18 maja 2012 r.; I. Sołomko, Mery priesieczienia, „Koriespondient” z 25 maja 2012 r. 
cjach występują w sposób cykliczny ${ }^{42}$ (tj. wyborów) i są one po prostu „wpisane” w jej istnienie? Czy - jeśli założyć chroniczność kryzysu (nie: kryzysów) - również nie uznać, iż - na wzór teorii cykli gospodarczych i politycznych M. D. Kondratiewa ${ }^{43}$ - Ukraina z każdego etapu kryzysu, wychodząc „obronną ręką”, nie wznosi się ku nowej, wyższej fazie? Wówczas, przy założeniu linearności (która notabene może ograniczać futurologa), przewidywanie rozwoju sytuacji wewnętrznej i zewnętrznej Ukrainy może być łatwiejsze. To jednak tylko upraszcza rzeczywistość. Wydaje się zatem, że wskazać możemy tylko główne trendy rozwojowe państwa ukraińskiego, szczegóły pozostawiając... przyszłości. Nie oznacza to oczywiście, że futurologię należy „skreślić”. Jest ona potrzebna chociażby po to, by „ćwiczyć” wszystkie scenariusze, nawet te, które na Ukrainie wydają się nierealne. Tylko wtedy będziemy „przygotowani na nieznane". Oby.

Prace nad zasadniczq treściq artykutu ukończono 4 sierpnia 2012 roku,

E. Donaj

42 Polityka bezpośrednio wiążę się z ekonomią. Zasadne zatem będzie przywołanie koncepcji politycznego cyklu koniunkturalnego. Zgodnie z nią rządzący politycy oddziałując na przebieg procesów gospodarczych są czynnikiem generującym, a nie wygaszającym cykl koniunkturalny. W swoich działaniach kierują się tym, by zwyciężyć w wyborach i utrzymać władzę. Dodawszy do tego emocjonalny charakter wyborów można odnieść wrażenie, że dla większości polityków kryzysy są wręcz niezbędne do tego, by móc wygrywać kolejne wybory. Pytanie tylko, czy jest to również z korzyścią dla wyborców... Ponadto, w odniesieniu do Ukrainy - możnaby - choć i w ugruntowanych demokracjach takie rzeczy się zdarzają - podnieść zarzut związany z brakiem cykliczności wyborów (patrz przedterminowe wybory parlamentarne na Ukrainie w 2007 roku, kwestia wyborów prezydenckich z 2004 roku czy obecnych. Zob. szerzej: Dylematy teorii ekonomii w rzeczywistości gospodarczej XXI wieku, pod red. A. Balcerzaka, D. Góreckiej, Torun 2007; Teoria ekonomii, t. 2: Makroekonomia, pod red. K. Meredyk, Białymstok 2000; Верховна Рада призначила вибори Президента на 25 жовтня, za: www. unian.net (data wejścia na strony: 29 stycznia 2010 r.); Czechy. Polska. Ukraina. Partie i systemy partyjne. Stan i perspektywy, pod red. K. Kowalczyka, Ł. Tomczaka, Toruń 2007.

${ }^{43}$ Nie brak oczywiście i sceptyków takiego podejścia. Należał do nich np.: Murray Rothbard. Zob.: Encyklopedia politologii, pod red. M. Żmigrodzkiego, t. 5: Stosunki międzynarodowe, pod red. T. Łoś-Nowak, Kraków 2002, hasło: Cykle rozwojowe (autor: T. Łoś-Nowak), s. 66-67; M. Rothbard, Cykl Kondratiewa - Fakt czy Oszustwo?, thum. J. Jabłecki, za: http://mises.pl (data wejścia na strony: 29 stycznia 2010 r.). 
The current socio-political crisis in Ukraine as an example of the cyclical (chronic?) nature of political processes

\begin{abstract}
Summary
The objective of scientific forecasting is to present the most probable course of an analyzed phenomenon, taking into account the direction and dynamics of its development. In the course of making forecasts one endeavors to determine the conditions providing for the evolution of this phenomenon. Twenty-something years of an independent Ukraine is decidedly too short a period to facilitate responsible hypothesizing on the development of internal and external situation of this country, but some suppositions are justified. On account of the limitations of this paper the author analyzes only selected events from the recent history of Ukraine.

The analysis does not answer the question of whether the recurring crises in Ukraine result primarily from phenomena that cyclically occur in a democracy (i.e. elections), and are simply inherent in it or not. Alternatively, when the chronic nature of a crisis (not: crises) is assumed, it may be concluded that as Ukraine emerges 'unscathed' from each stage of the crisis it evolves towards a new, more advanced phase, in consistence with Kondratiev's theories of economic and political cycles.
\end{abstract}

